\title{
Home Bias and the Real Estate Prices
}

\author{
Hsiu-yun Chang ${ }^{1}$ \\ ${ }^{1}$ Department of Finance and Banking, Aletheia University, New Taipei City, Taiwan \\ Correspondence: Hsiu-yun Chang, Assistant Professor, Department of Finance and Banking, Aletheia University, \\ No.32, Zhenli St., Danshui Dist., New Taipei City 25103, Taiwan. Tel: 886-2-2756-2236.
}

Received: February 9, 2017

Accepted: March 22, 2017

Online Published: April 8, 2017

doi:10.5430/ijfr.v8n2p145

URL: https://doi.org/10.5430/ijfr.v8n2p145

\begin{abstract}
This paper argues that the Home Bias phenomenon prevails in the real estate market, which is inferred from psychology, economic, and financial literature. Utilizing the trait of the Home bias behavior, which can reduce the risk of information asymmetry, I modify the classical pure trading model and employ the parameter of relative risk aversion as the proxy variable of Home Bias to translate the relationship among Home Bias phenomenon, the property prices, and the expected returns.

The comparative static analyses indicate that Home Bias behavior is negatively related to the property prices and positively related to the property returns. The marginal effects on property prices are heightened in situations of high time preference and relative low Home Bias. Conversely, the marginal effects on property returns are larger if the time preference parameter is smaller. As a household buyer with high time preference is located far away from a property, his bargaining power is easily affected by home bias behavior. Further, this paper focuses on the home bias elasticity of property prices and returns for the sake of unit-free property. Inelastic coefficients of elasticity of prices and returns indicate that the capability of households to lower property overvalued prices (i.e. increase investment returns) from reducing information asymmetry by using Home Bias behavior is still limited.
\end{abstract}

Keywords: asset pricing model, home bias, information asymmetries, real estate price, risk aversion

JEL Classifications: G00, G33, G39

\section{Introduction}

There are two main objectives of the study. The first objective of this paper is to announce the argument of Home Bias phenomena prevalent in real estate market. This argument can be manifested from interdisciplinary research which can be generalized into two major academic tributaries about housing location decisions. First is emotional attachment, social ties, family ties, social network debated by sociologists, geographers, demographers and psychologists; second is the information asymmetry explored by economist and financial scholar. The second objective of this paper is to modify the Lucas (1978) model, to re-derive closed-form solution for equilibrium local property prices, and furthermore to explore how Home Bias phenomenon affect equilibrium prices and expected returns of local properties.

Home bias is an often-seen terminology in international business and stock markets. In macroeconomic studies, Lewis (1999) and Baxter and Jermann (1997) mentioned that consumption home bias is the preference to buy domestic products. Home bias of stock markets is to describe that investors hold more domestic stocks and hold less foreign assets and foreign investment products (Coval and Moskowitz 1999). In real estate markets, there is serious market segmentation in each administrative district. Each has different trading price indexes and demand preference and each administrative district is a scaled-down country. Thus, the home bias term is more suitable in real estate markets. Furthermore, we can see that contemporary real life is generally filled with Home Bias phenomenon.

As people live in one place longer along with changes in their economic conditions and the environment, then living dissatisfied and residential inertia would be derived. The longer the residential duration takes, the worse the living condition will become in this house. Eventually, all problems accumulate into a residential stress and then households have relocation demand (Brown and Moore 1970; Simon 1957). After long deliberation and plans, then household decided to move out. Or at the time of an adult child's departure from his parental home because of marriage, the choices of a house and housing location become a deep science. Some households, proceeding with their new destination choice of homeowner, would prefer to live near the original location. Under some 
circumstances, as adult children moved out of the original habitat or the original co-residence with their parents, they were inclined to live in the vicinity of their family members. Hedman (2013) also proved the hypothesis of 'Having family members (or previous experience) in a neighborhood is positively correlated with the probability of choosing that neighborhood as the destination.' These are defined herein Home Bias phenomenon.

The second contribution of this paper is to introduce Home bias behavior into utility function. In administrative districts with high information asymmetry, buyers will buy their properties nearby to decrease insufficient information risk to prevent the possibility of over-estimating real estate prices. Home bias is definitely a preference feature in real estate markets. Price reduction of over-estimated real estate can indirectly improve the utility of buyers. The less that buyers overestimate real estate prices, the higher utility investors can gain. On the contrary, the more they overestimate, their utility is less. To formulate the representative household consumption utility function, this study refers to the model setting of Constantinides (1990) who introduced consumption behavior into utility function. Past consumption behaviors are also influential factors of utility function. For the representative household purchasing behavior, the overestimated or underestimated levels are different in different administrative districts under different information asymmetry levels. This will result in different happiness levels after the representative household bought the property.

The remainder of this paper is organized as follows. Section 2 reviews psychological and financial literature to derive and demonstrate that the real estate market is awash with Home bias phenomenon. Section 3 constructs the home bias model, derives the closed-form solutions for the property prices and expected returns, and outlines the theoretical propositions. Section 4 calibrates the results of comparative static analyses and elasticities in section 3 . Section 5 Concludes.

\section{Literature Review for Home Bias Phenomenon}

\subsection{Social Psychology and Home Bias}

Focusing on the social psychology perspective, housing location decisions would be affected by emotional attachment, social ties, family ties, the behavior of family members, the traditional Chinese concept of filial piety, social network, etc. People will, through acquaintances, relatives, memory, or any interaction with the environment, love an area. With growing substantial or emotional bondage, people will not easily give up the environment with their previous experience.

Emotional attachment is defined as affective bond that people develop with their places of residence (Manzo 2005) and it is also named place attachment in Bonaiuto et al. (1999), Lewicka (2008; 2010; 2013), and Wall and Reichert (2013). Although the definition of emotional attachment is somewhat different from the definition of place attachment, studies presented in this paper concern emotional attachment to neighborhood (or community) and home. (Note 1) The strength of emotional attachment will be affected by demographic and social factors. According to sociologists, geographers, demographers and psychologists, the relatively significant demographic factors include length of residence (Bonaiuto et al. 1999; Brown et al. 2003; Brown, Perkins, and Brown 2004; Kasarda and Janowitz 1974; Krannich and Greider 1984; Shamai and Ilatov 2005; Lewicka 2008; Shamai and Ilatov 2005), age (Cuba and Hummon 1993; Ng et al. 2005; Shamai and Ilatov 2005), and home ownership (Bolan 1997; Brown et al. 2003; Lewicka 2013; Mesch and Manor 1998; Ringel and Finkelstein 1991). Social ties and sense of security (Brown et al. 2003, 2004; Mesch and Manor 1998) are the two most often studied positive social factors. The following variables can be treated as the elements of social ties: number of friends and relatives in neighborhood; interest in family roots and in the history of residence place (Chrząstowski and Lewicka 2008; Connerly 1986; Dawkins 2006; Landale and Guest 1985; Spilimbergo and Ubeda 2004; Wójcik et al. 2010); trust in neighbors and trust in close persons (Glanville and Paxton 2007; Portes and Landolt 1996).

The relation between emotional attachment and residential stability has bidirectional causalities. The increased mobility of residents would collapse local communities, and further damage the strength of community attachment (Kasarda and Janowitz 1974). On the other hand, residential stability can result in stronger identification with one's community, which was found by Oishi et al. (2007) who preceded a series of experimental studies on the emotional and behavioral consequences of residential stability. However, according to the concept of emotional attachment, residents with stronger identification with their community can also result in higher residential stability. Consequently, if household in high community attachment place has the demand of relocation, he would choose tenure home bias.

Part of the literature on location decisions narrowed the focus on family ties. Several had investigated the correlation between parents' financial transfers to adult children and the effects of such transfers on the attainment of personal 
care or assistance in the event of disability or poor health (Cigno et al. 1998; Henretta et al. 1997; McGarry and Schoeni 1995, 1997; Pezzin and Schone 1999; Soldo and Hill 1995). Hedman (2013) emphasized that according to the three hypotheses of affinity, facilitating, and information, household could increase the home bias effect on their relocation decisions. Tomassini et al. (2003) focused on the parent-child proximity and found that parental housing assistance at the time of marriage has a strong effect on the child's choice of location, on the initial and persistent spatial proximity to parents, especially on the proximity to husband's parents in some situations. The strength of familial affective ties is positive correlatively with spatial proximity. Knijn and Liefbroer (2006) emphasized that if the family members lived more than 5 kilometer away, the probability of receiving or giving assistance was actually decreased. Affection, social contacts, and geographic distance among family members are strongly interrelated (Dewit et al. 1988; Knijn and Liefbroer 2006; Lawton et al. 1994).

Households may move near their parents, adult children, siblings or other family members because they are used to favoring associated types of environments (Blaauboer 2011; Feijten et al. 2008, Hedman 2013; Mulder 2007). Although good quality childcare is provided and affordable for every household in Sweden, households are likely to move to neighborhoods where extended family members reside in (Hedman 2013). This home bias phenomena of family ties can be observed in many countries over the world such as Portugal, Spain, and Italy (Tomassini et al. 2003), Turkey and Morocco (Zorlu 2009), Pakistani households in Glasgow (Bowes et al. 1997), and Asian countries especially. Co-residence was prevalent in the Asia-Pacific region, where have the following characteristics: 1.) deeply affected by the traditional Chinese concept pf filial piety; 2.) having strong intergenerational links, living patterns of co-residence; 3 .) prevalent economic and noneconomic flows between parents and children. However, with the development of urbanization, modernization, industrialization, and the conflict of co-residence, the length of co-residence with parents has decreased after marriage or further, the intergenerational co-residence life gradually transformed into the nuclear family. (Lowenstein 2002; $\mathrm{Ng}$ et al. 2002). Instead of co-residence, the majority households with the traditional Confucian filial piety would choose to live near their parents or family members in Asian societies. No doubt the home bias phenomenon of housing location occurs almost all over the world.

Besides, people move towards their parents, siblings, and other family members, as they suffer special life events or profound changes when the need of support is particularly affective or functional, such as during divorce, marital separation, or the birth of children (Michielin et al. 2008; Wall and Reichert 2013).

Through emotional attachment, social ties, or family ties, People and things living in a specific space can be woven into a complex social network. Chin (2010) found that the impact of social networks on the intentions or preferences of location decisions is not less than the rationality of microeconomics. Economic benefits are visible, computable, and more well-known; however, the power of social network is invisible, insubstantial, and difficult to estimate. Social network can create, cumulate, and solidify social capital in neighborhood through trust, co-operation, collective support and norms (Chin 2010; Bourdieu and Wacquant 1992; Portes and Landolt 1996). In large part social networks are tied to the physical location and relocation would cause greater the transaction costs for better social network (Durlauf and Fafchamps 2005; Glaeser et al. 2002; Jacob and Munasib 2009; Munasib 2009). Dipasquale et al. (1999) find that homeownership gives household an incentive to improve the environment of their neighborhood, encourages household to invest in local amenities, and furthermore, solidifies the social network. Consequently, as the household with deeper social network confront the living disequilibrium or encounter the demand of relocation, ceteris paribus he would have a greater incentive to relocate in the same community where he has previous experience to cost down the transaction cost.

\subsection{Financial Economics and Home Bias}

The information asymmetry is another academic tributary to explain the Home bias phenomena of real estate market. Many literature have proven that Information asymmetry seriously exists in real estate markets (Cooper, et al. 2000; Cutts and Order 2005; Firoozi et al. 2006; Garmaise and Moskowitz 2004; Green 2008; Levitt and Syverson 2008; Rutherford et al. 2007; Wong et al. 2012). The asymmetry of information with respect to property prices comes from two sources. First, sellers have more complete information of their local district and its surrounding environment, including economic and social activities. And, they are more knowledgeable of the local government regulation and the neighborhood facilities which have impact on property prices. Second, sellers have more precise information of the merits and drawbacks of the building materials and structure. The above sources of information asymmetry are both important factors to decide property prices. Consequently, lack of property knowledge is a barrier to becoming a homeowner (Haurin and Morrow-Jones 2006). To improve the asymmetric information of buyers, some countries and local government have regulated to disclose some key items of real estates. The approval of disclosure acts reduces information asymmetry, on the contrary, increases the real estate prices (Nanda and Ross 2012). But, 
disclosure of seriously negative spillover effects reduces these real estate prices significantly (Pope 2008). This is a strong evidence that information asymmetry is highly correlated with real estate prices.

Garmaise and Moskowitz (2004) prove that buyers will buy properties near their original residence to mitigate information asymmetries, especially in high asymmetric information area, which means that shorter distance between properties and buyers represents more knowledgeable about properties conditions. The Home bias phenomenon indirectly observed on the information asymmetry topic of real estate by Garmaise and Moskowitz. Some literature can indirectly demonstrate the relationship between distance and information via channels of family or social networks. According to the information hypothesis of Hedman (2013), having family in a neighborhood could increase cognitive knowledge about that area. Households always search residences within an awareness and contact space. By way of family or family members, awareness and contact of an area would be encouraged (Brown and Moore 1970; Quigley and Weinberg 1977; van Kempen and Özüekren 1998).

Through the channel of social networks, households can obtain crucial knowledge and information about household finance, wealth management, home maintenance, housing market, etc.; furthermore, homeownership and locational stability can be achieved (Durlauf and Fafchamps 2005; Jacob and Munasib 2009). Throughout the world real estate transactions are full of home bias phenomena.

\section{The Modified Lucas (1978) Asset Price Model and Propositions}

Purchasing behavior of real estate was driven by dual motives of self-resided and investment demands (Arrondel and Lefebvr, 2001; Henderson and Ioannides 1987; Hung and So 2012). No matter which motivation triggers purchasing behavior, location selection is very important. Real estate price is determined by two factors. One is the characteristics of the building, including structure, building materials and design. The other is the land, section characteristics, the spillover effects of surrounding environment and facilities and even the future city development roadmap (Dietz 2002; Haurin et al. 2002; Ioannides 2002; Manski 1993, 2000). Spillover effect of surrounding environment and facilities could be side benefits or side effects. Side effects of neighborhood characteristics, such as traffic noise or aircraft noise, will have negative impact on real estate prices (Nelson 1978, 1979, 1980, 1982). High unemployment rate and crime rate of a particular section will reduce buyers' demand of those real estates (Corcoran et al. 1992; Crane 1991). Side benefits of neighborhood characteristics, such as high education standard, high population density, high income, complete medical facilities and complete park plans, will increase the real estate prices (Benabou 1996; Durlanf 1996).

According to the theoretical and empirical literature review above and asset pricing model, I derive some propositions about relationship between Home Bias and real estate prices. By modifying the classical pure trading model Lucas (1978), I demonstrate the effects of Home Bias on real estate prices and its expected return, and further to map the volatilities in Home Bias factor to the volatilities in local property prices.

Proposition 1. The risk attitude factor of Lucas (1978) model can be employed as Home Bias factor in real estate market.

First, recall the article of Garmaise and Moskowitz (2004), they have empirically verified that shorter distances between buyers and properties can mitigate information asymmetry of property buyers. In other words, property buyers can reduce their risk by buying properties nearby. Second, risk aversion buyers will release serious nature of Home Bias in order to diminish bothersome risk and to enhance their investing utility. Accordingly, the degree of severity of home bias can be reflected by the degree of risk aversion.

Asset pricing is always an important topic in finance theory and real estate pricing is also an important research area in urban economics. Therefore, this paper further amends Lucas (1978) model to interpret and present the phenomenon of real estate investment.

\subsection{Preference Setting}

In accordance with Garmaise and Moskowitz (2004) s' argument, Home Bias can reduce the risk of information asymmetry. Thus, a real estate investor with a stronger risk aversion tendency, whose Home Bias phenomenon is stronger, because it can reduce the risk. Using Lucas (1978) model to translate the relationship between Home Bias and a property price, I can use the parameter of relative risk aversion as the proxy variable of Home Bias defined as distance preference. As the real estate investor buys a property near their original residence, which would reduce the risk of information asymmetry. Lower risk makes the risk aversion investor happier, then enhancing the utility of the investor. No doubt, it's appropriate to employ risk attitude, $\phi$, as the proxy variable of Home Bias.

We hypothesize $d \in[0, \infty]$ as the distance between the representative buyer's new properties and their original 
residence. Lower $d$ leads to more home bias phenomena. When the buyer becomes more risk averse, he behaves more home bias, and then buys closer properties. Because shorter distance can alleviate the buyer's information asymmetry risk. Risk aversion prefers low risk. The representative buyer now wants to maximize his whole-life utility when choosing his own consumption and real estate goods for each period.

The model is set as follows.

$$
U_{t}=\mathrm{E}_{t}\left[\sum_{s=t}^{\infty} u\left(c_{s}\right)\right],
$$

where $\mathrm{E}_{t}[\cdot]$ is the expected value of total utility under all collectable information at time of $t . u\left(c_{s}\right)$ is the utility function of representative household at time of $s . c_{s}$ is the units of consumer goods which the representative household will purchase at time of $s$.

The model setting of consumption utility function of representative households is referred to Constantinides (1990), who successfully introduced consumption behaviors into utility function setting. This means the past consumption behaviors can be considered as factors of utility function. When representative households purchase real estates in different districts under different information asymmetry, the over-estimation extents will be different. This will cause representative households have different happiness after their consumption behavior. Considering the above-mentioned feature, this study adds consumption behaviors factors into utility function and introduces Home bias factor of real estate markets into utility function based on our logical inference. Moreover, we limit the utility function as a CRRA (Constant relative risk aversion, CRRA) function. Therefore, the utility function of this representative household at time of $s$ can be formulated as follows.

$$
u\left(c_{s}\right)=\beta^{s-t} \frac{c_{s}^{1-\phi}}{1-\phi}, \quad 0<\phi<1,
$$

where $\beta$ of Eqn. (2) is subjective time preference and it has another clear economic meanings that a representative buyer is willingness to postpone recent consumption activities to future time periods. $\alpha$ is the level of relative risk aversion. $u\left(c_{s}\right)$ is a strictly increasing convex consumption function. Thus, $\partial u / \partial c>0, \partial^{2} u / \partial^{2} c<0$.

Assume at time of $t$, only real estate goods have productivity to produce consumer goods which may perish. This productivity comes from the incremental value of real estate, $y_{t}$, during this time period. Assume real estate is trading at a perfectly competitive market and representative household can only trade one unit of real estate goods. Thus, the return of this representative household represents the return of total market.

According to asset pricing theory (Cochrane 2001; Donaldson and Mehra 1984; Duffie 2001; Lucas 1978; Prescott and Mehra 1980), the followings discuss the intertemporal equilibrium consumption decision of the representative household at time $t$. If the household invests one unit of real estate, the purchasing units of consumer goods will decrease $p_{t}$. For this representative household, the total utility will be down for $p_{t} u^{\prime}\left(c_{t}\right)$. Due to the incremental value of real estate, the household can purchase additional $p_{t}+y_{t+1}$ units of consumer goods, at time of $t+1$, as he holds the real estate until next period. This will increase his marginal utility of $E_{t}\left[\left(p_{t}+y_{t+1}\right) u^{\prime}\left(c_{t+1}\right)\right]$. To the viewpoint of optimal equilibrium, the marginal utility loss of investing real estate at time $t$ will be equal to the increased marginal utility of divesting the real estate at time $t+1$. Thus, we can obtain Eqn. (3):

$$
p_{t} u^{\prime}\left(c_{t}\right)=E_{t}\left[\left(p_{t}+y_{t+1}\right) u^{\prime}\left(c_{t+1}\right)\right]
$$

From the viewpoint of real estate returns, the Eqn. (4) can be obtained from (3): 


$$
1=E_{t}\left[\frac{u^{\prime}\left(c_{t+1}\right)}{u^{\prime}\left(c_{t}\right)} \cdot R_{t+1}\right]
$$

where $R_{t+1}=\left(p_{t}+y_{t+1}\right) / p_{t}$.

To further develop the Lucas-type pure transaction model of real estate markets, we make the following four assumptions (Note 2):

A. 1: consumption growth rate $\left(g_{t+1}=c_{t+1} / c_{t}\right)$ follows Markove process. Then, dynamics of consumption growth rate is described by the geometric Brownian process: $d g=\mu g d t+\sigma g d z$ where $z$ is unit of Weiner process. Thus $g$ follows the lognormal distribution with expected value of $\mu-\frac{1}{2} \sigma^{2}$ and variance of $\sigma^{2}$. $\mu$ and $\sigma$ are the drift and volatility, respectively, per unit time. The unit time period is set to be one year.

A. 2: the consumption growth rate, $g$, and real estate return, $R$, are identically and independently distributed (i.i.d.).

A. 3: Assume $p_{t}$ is homogeneous of degree 1 in $y_{t}$, let $h_{t}$ is the price- incremental value ratio at time $t$

(i.e. $h_{t}=\frac{p_{t}}{y_{t}}$ ) and is i.i.d.. Then, we can derive $p_{t}=h_{t} y_{t}$.

A. 4: We further assume growth rate of incremental value of property is identical to the consumption growth rate.

Thus, $g_{t+1}=\frac{c_{t+1}}{c_{t}}=\frac{y_{t+1}}{y_{t}}$.

We can obtain:

$$
\frac{u^{\prime}\left(c_{t+1}\right)}{u^{\prime}\left(c_{t}\right)}=\beta \cdot g_{t+1}^{-\phi}
$$

The Closed-form Solutions of Property Prices and Expected Returns

Substitution of (5) into Eqn. (4) yields

$$
1=E_{t}\left[\beta g_{t+1}^{-\phi} R_{t+1}\right]
$$

Accordingly, based on assumption A.3, property return can be rephrased as:

$$
R_{t+1}=\frac{p_{t}+y_{t+1}}{p_{t}}=1+\frac{y_{t+1}}{p_{t}}=1+\frac{y_{t+1}}{h_{t} y_{t}}=1+\frac{g_{t+1}}{h_{t}}
$$

Substitution of (7) into Eqn. (6) yields

$$
h_{t}=\frac{\beta E_{t}\left[g_{t+1}^{1-\phi}\right]}{1-\beta E_{t}\left[g_{t+1}^{-\phi}\right]}
$$

According to assumption A. 1, we can obtain: 


$$
\begin{aligned}
& E_{t}\left[g_{t+1}^{-\phi}\right]=e^{\phi\left(\frac{\phi \sigma^{2}}{2}+\frac{\sigma^{2}}{2}-\mu\right)} \\
& E_{t}\left[g_{t+1}^{(1-\phi)}\right]=e^{(1-\phi)\left(\mu-\frac{\phi \sigma^{2}}{2}\right)}
\end{aligned}
$$

The detailed deduction process of Eqns. (9) and (10) is as appendix A.

Substituting Eqns. (9) and (10) into (8), the property price can be written as below:

$$
p_{t}=y_{t} \frac{\beta e^{(1-\phi)\left(\mu-\frac{\phi \sigma^{2}}{2}\right)}}{1-\beta e^{\phi\left(\frac{\phi \sigma^{2}}{2}+\frac{\sigma^{2}}{2}-\mu\right)}}
$$

The expected returns of property returns can be derived by Eqns. (7), (8), (9) and assumption A. 3:

$$
E_{t}\left[R_{t+1}\right]=E_{t}\left[1+\frac{g_{t+1}}{h_{t}}\right]=1+\frac{1-\beta e^{k}}{\beta e^{l}}
$$

where as $k=\frac{\phi^{2} \sigma^{2}}{2}+\frac{\phi \sigma^{2}}{2}-\phi \mu$,

$$
l=\frac{\phi^{2} \sigma^{2}}{2}-\frac{\phi \sigma^{2}}{2}-\phi \mu
$$

\subsection{Fluctuations in Property Prices Induced by Home Bias Phenomenon}

For measuring the determination of the changes in equilibrium prices that will result from a change in home bias parameters of that equilibrium, the comparative static analysis is carried out by partially differentiating Eqn. (11) with respect to home bias factor. It follows that,

$$
\frac{\partial p_{t}}{\partial \phi}=-y_{t} \beta e^{m} \frac{\left[\mu+\left(\frac{1}{2}-\phi-\beta e^{k}\right) \sigma^{2}\right]}{\left(1-\beta e^{k}\right)^{2}}
$$

Where $m=(1-\phi)\left(\mu-\frac{\phi \sigma^{2}}{2}\right)$.

Proposition 2. The trading price of real estate will be lower, as the distances between buyers and properties are relatively shorter.

For the sake of unit-free property, furthermore, the home bias elasticity of real estate price, denoted by $\varepsilon_{p, \phi}$ is derived. It can measure the percentage change in property prices that result from one percentage change in home bias factor. Hence, the formulas for measuring the coefficient of the home bias elasticity of property price is:

$$
\varepsilon_{p, \phi} \equiv \frac{\partial \ln p_{t}}{\partial \ln \phi}=-\frac{\left[\mu+\left(\frac{1}{2}-\phi-\beta e^{k}\right) \sigma^{2}\right] \phi}{1-\beta e^{k}}
$$


Proposition 3. Variations of Home Bias phenomena induce negative property price variations.

Fluctuations in Property Returns Induced by Home Bias Phenomenon

Advanced analysis with property return is proceeding. The comparative static analysis for expected returns of properties is carried out by partially differentiating Eqn. (12) with respect to home bias factor. Hence,

$$
\frac{\partial E\left[R_{t+1}\right]}{\partial \phi}=\frac{\left[\mu+\left(\frac{1}{2}-\phi-\beta e^{k}\right) \sigma^{2}\right]}{\beta e^{l}}
$$

Proposition 4. The expected returns of properties will be higher, as the distances between buyers and properties are relatively shorter.

Proposition 5. The partial derivative of returns to home bias factor is relatively higher for a household with low time preference.

A household with lower time preference would be more willing to sacrifice current consumption to buy closer property, therefore he has more opportunity to get higher returns.

The formulas for measuring the coefficient of the home bias elasticity of property expected return is:

$$
\varepsilon_{R, \phi} \equiv \frac{\partial \ln E\left[R_{t+1}\right]}{\partial \ln \phi}=\frac{\left[\mu+\left(\frac{1}{2}-\phi-\beta e^{k}\right) \sigma^{2}\right] \phi}{1+\beta e^{l}-\beta e^{k}}
$$

Proposition 6. Variations of Home Bias phenomena induce positive variations of property returns.

\section{Calibrations}

\subsection{Calibrations for Fluctuations in Property Prices}

I use the parameter values of $\mu=0.018$ and $\sigma=0.035$ estimated by Mehra and Sah (2002) for per capita real consumption of non-durables and services, and then Eqns. (13) and (14) can be calibrate by setting the incremental value of real estate as 200 . The parameter $\phi$, which measures the curvature of the utility function, the level of relative risk aversion, and Home Bias phenomenon, is an important one in financial economics. Some researchers suggest that the parameter of risk aversion is smaller than or near 1 (the logarithmic risk-aversion). Altug (1985) uses econometric techniques to estimate $\phi$ to be approximately 0. Arrow (1971) summarizes a number of studies and concludes that $\phi$ should be near 1, the argument is supported by Kehoe (1984), studying the topic of international trade. Consolidating different advices from experts and scholars, this study calibrates the model result with $0<\phi \leq 1$.

However, others suggest that the parameter of relative risk aversion is larger than 1. Friend and Blume (1975) suggest that $\phi$ should be set in the range of 2 for the researching the portfolio holdings of individuals. Tobin and Dolde (1971) set a value of 1.5 for $\phi$ to fit the life cycle savings model. Mehra and Prescott (1985) and Shu (2010) set alpha between 1 and 10, Mehra and Sah (2002) carried out their numerical analysis with $1.01 \leq \phi \leq 3$. For robustness check, this study calibrates Eqns. (13) and (14) with $\phi=1,2$, and 3. All results are reported in Figure 5 and Figure 6 of Appendix B, which are consistent with Figures 1 and 2 respectively.

The corresponding Figures of calibrations of Eqns. (13)-(14) are displayed respectively in Figures 1 and 2 . In Figure 1 , it is apparent that the partial derivative of property price with respect to $\phi$ is negative, which means that property prices fall as the household becomes more home-biased. Higher $\phi$ is associated with lower property prices, which Proves Proposition 2. This is aligned with the arguments from Garmaise and Moskowitz (2004), the household tend to buy closer real estates to mitigate the overvalued situation of property prices caused by highly information asymmetry between buyers and sellers. Figure 1 also shows an interesting appearance. The marginal effects of the home bias factor are heightened in situations of high $\beta$ and relative low $\phi$, revealing that a household buyer with high time preference and located far away from a property is easily affected by home bias behavior when pricing real estate. This result reflects the market segmentation of different administrative regions. As one buyer who originally want to buy a property in other administrative region transfers to buy a property in the same administrative region, this home bias behavior can reduce the considerable information asymmetry, and thus greatly reduce the price overestimated phenomenon. Conversely, as one buyer who originally want to buy a property in the same administrative region transfers to buy a property closer and still in the same administrative region, this kind of home bias effect will be significantly reduced. 
Figure 2 displays the elasticity, $\varepsilon_{p, \phi}$, interpreting the percentage change of the fractional fluctuations in property prices induced by the one percentage of the fractional fluctuations in the Home Bias parameter. The results in Figure 2 provide support for proposition 3. All absolute values of coefficients of the home bias elasticity of property prices are smaller than one; in other words, it's inelastic. The variations of home bias phenomena induce smaller negative price variations in the real estate market. The buyer can reduce information asymmetry risk by knowing the environment of the property and the property itself through the shorter distance, and thereby bargain with the seller to abate the proportion of the price overvalued. However, the ability to decrease information asymmetry and to restrain overvalued range is still limited. Figure 2 also shows that the coefficient of the home bias elasticity of price are heightened in situations of high $\beta$ and high $\phi$.

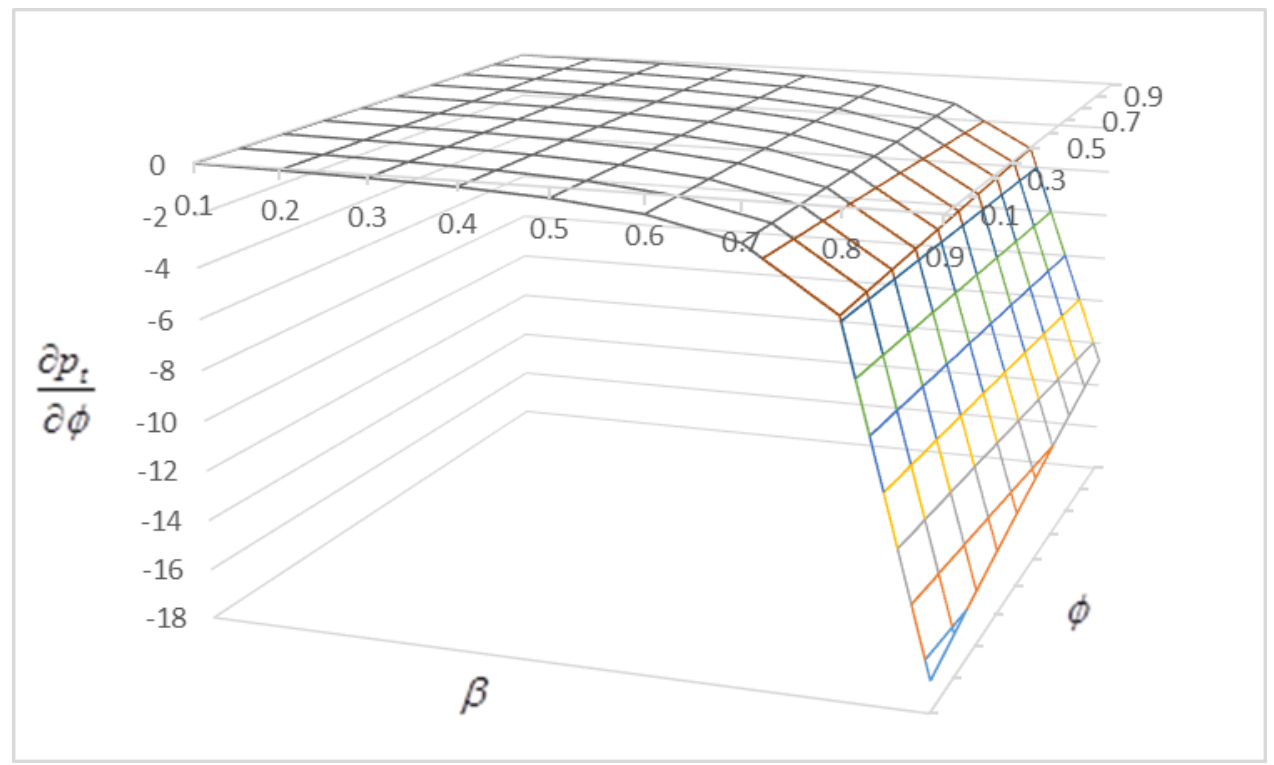

Figure 1. The partial derivative of property price with respect to home bias factor

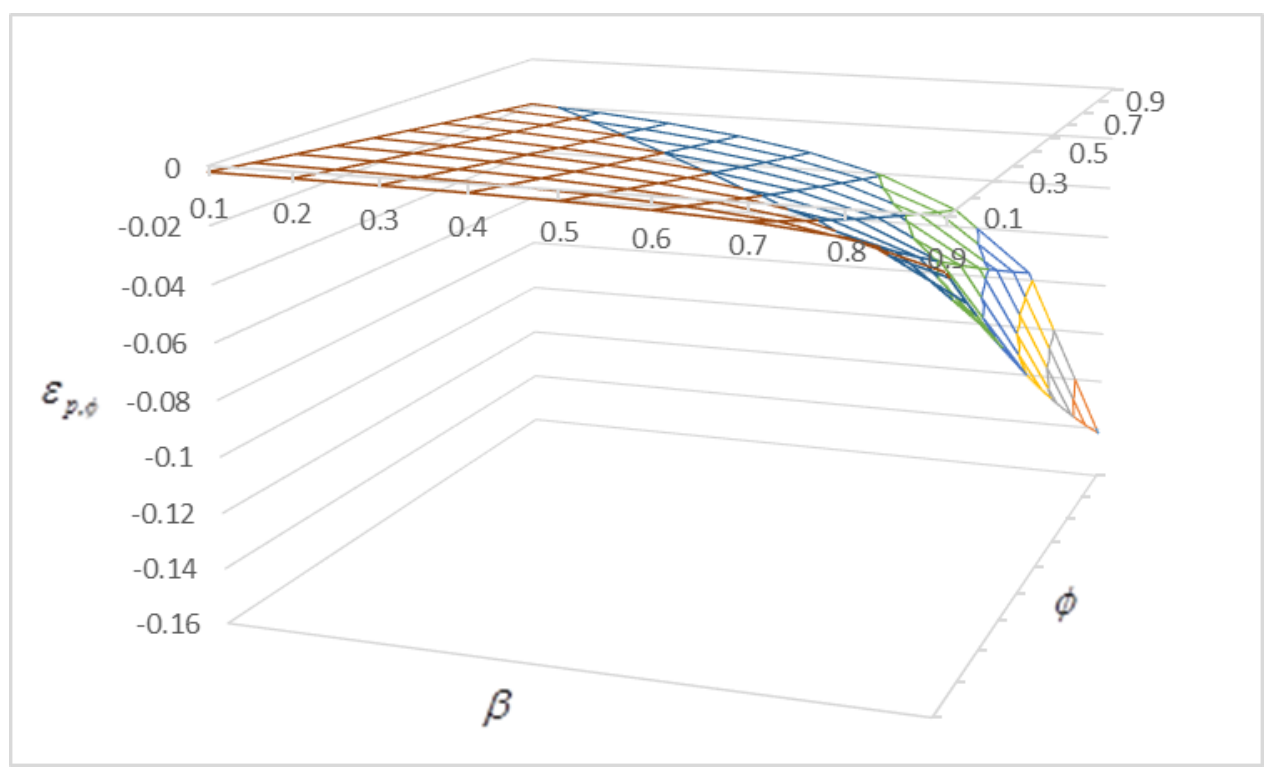

Figure 2. The coefficient of the home bias elasticity of price 


\subsection{Calibrations for Fluctuations in Property Returns}

All the calibration results of the comparative static analyses and the coefficient of elasticity of expected returns are displayed Figures 3 and 4. Figure 3 demonstrates that the partial derivative of property return with respect to $\phi$ is positive, which is consistent with Proposition 4. Property returns increase as the household becomes more home-biased. To catch high expected returns, the more risk aversion household would be willing to sacrifice current consumption to buy closer property with higher expected returns. To sum up the findings of Figure 1 and Figure 3 in comparative static analyses, property prices and expected returns exist the following relationship in real estate market: the property prices in period $t$ fall as $\phi$ increases, and furthermore this diminished period price will increase the expected returns of the next period. According to these relationships, we can conclude that the real estate price has the mean reverting property so that it will tend to move to the average price over time. Deviations from the average price are expected to revert to the average. Figure 3 also reveals an interesting outcome. The marginal effects of the home bias factor on property returns are larger if the time preference parameter is smaller, which verifies Proposition 5. As a household buyer with high time preference is located far away from a property, his bargaining power is easily affected by home bias behavior when pricing real estate.

The calibration results of the home bias elasticity of expected return are drew on Figure 4, which shows clearly that the coefficient of the home bias elasticity of expected return for property is positive inelastic $\left(0<\varepsilon_{R, \phi}<1\right)$ in all

case of $\phi$ considered in Figure 4. Regardless of the degree of information asymmetry in the real estate market, the

percentage change in expected return is positively related to the percentage change in $\phi$, as described in Proposition 6. Furthermore, the total variations of property returns induced by variations of Home Bias phenomena are higher if the Home Bias parameter is higher. I redraw the calibrations of Eqns. (15) and (16) for $\phi=1,2$, and 3 in Figure 7 and Figure 8 of Appendix B, which have similar results with Figures 3 and 4.

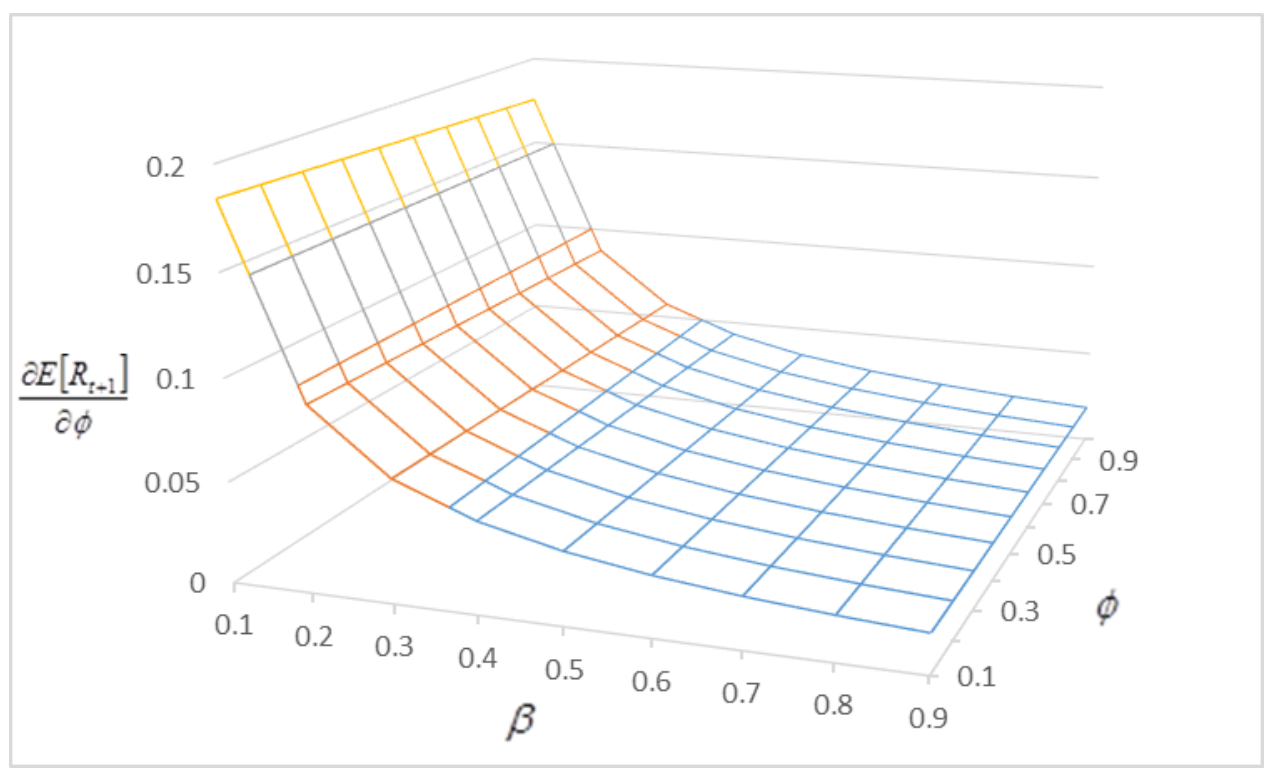

Figure 3. The partial derivative of returns with respect to home bias factor 


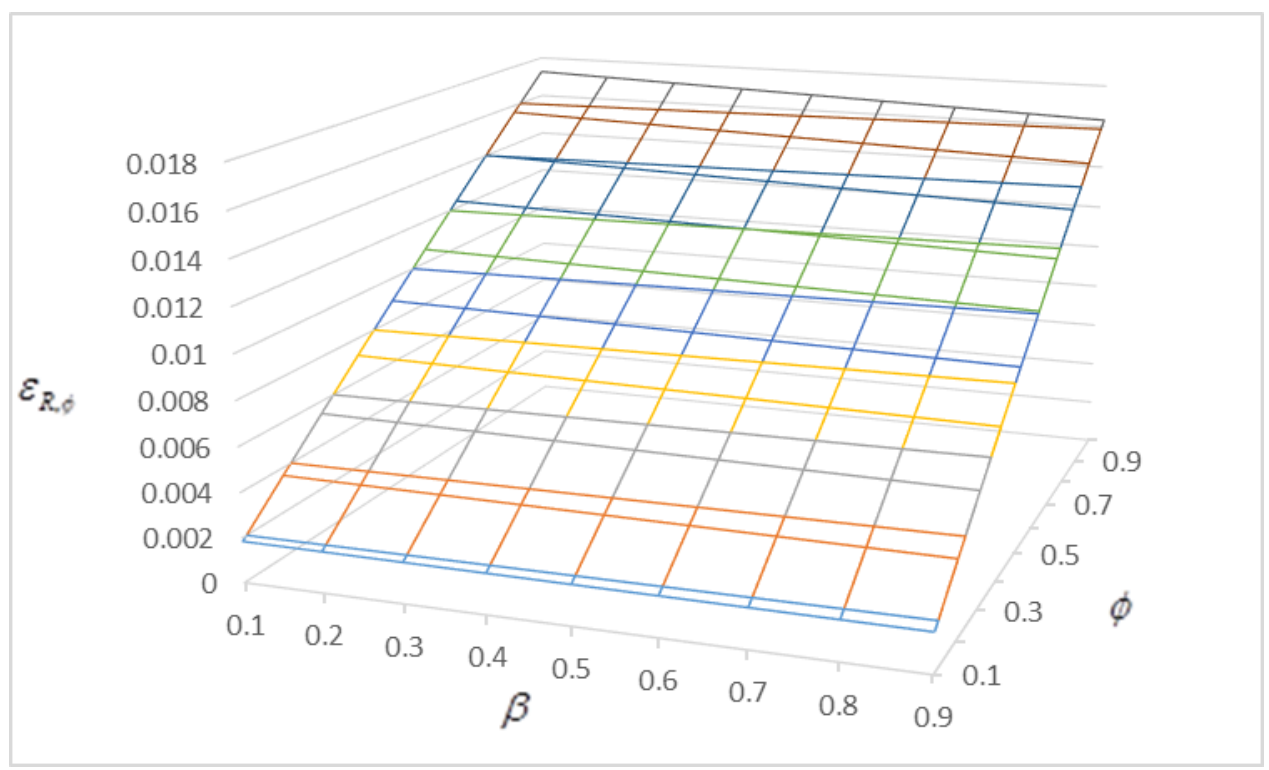

Figure 4. The coefficient of the home bias elasticity of return

\section{Conclusion}

The real estate market is a representative Lemon market. It is full of information asymmetry, which occurs when the seller knows more about a property than the buyer. However, the academic articles discussing the information asymmetry topic in real estate market are relatively few. Above all this article proposes that the real estate market is full of Home Bias phenomenon, which are proved by researches of social psychology perspective, economist, and financial scholars. Furthermore, for echoing with the ecosystem, this article introduces the behavior of biological communities into the real estate pricing model for measuring the variation influence of home bias factor on the property prices and returns. By way of developing the theoretical framework for the home bias phenomena induced by information asymmetry, this article will be helpful to understand the seriousness of information asymmetry in real estate analysis and the impact of investors' purchase behavior on property prices and expected returns.

In order to improve the serious asymmetry of information on the real estate market, people develop a home-biased purchasing behavior and like to buy assets which are easier observed. This purchasing behavior mitigates the information asymmetry risk. According to modified Lucas (1978) asset pricing model, this study finds that the real estate prices follow mean reverting process. The Home Bias behavior can mitigate overvalued situation in lemon market and the marginal negative effects will decrease as the Home Bias phenomenon increases. Furthermore, the article has assessed the variations of property prices induced by slight variations in Home Bias factors through elasticity. The results demonstrate that the Home Bias elasticities of property prices are smaller than 1 , which means that variations in household's information cause smaller variations in property prices. Therefore, if a household want to suppress overvalued property prices through shorter distance, the affected rage is relatively limited.

In addition, I account for the effect of Home Bias factors on the property returns. This article shows that property returns increase as the household becomes more Home Bias. The marginal effects of the Home Bias factors on property returns are larger as the time preference parameters are smaller. The Home Bias elasticities of property returns are still inelastic, t.

\section{Acknowledgment}

I thank Woan-lih Liang, an associate professor of National Chiao Tung University, for helpful comments and suggestions.

\section{References}

Altug, S. J. (1983). Gestation Lags and the Business Cycle: An Empirical Analysis, Gestation Lags and the Business Cycle: An Empirical Analysis. Carnegie-Mellon working paper, 1983, Presented at the Econometric Society meeting, Stanford University, Carnegie-Mellon University, Pittsburgh, PA. 
Arrondel, L., \& B. Lefebvre. (2001). Consumption and Investment Motives in Housing Wealth Accumulation: A French Study. Journal of Urban Economics, 50(1), 112-137. https://doi.org/10.1006/juec.2000.2209

Arrow, K. J. (1971). Essays in the Theory of Risk-Bearing Published. North-Holland, Amsterdam Markman, Chicago.

Baxter, M., \& U. J. Jermann. (1997). The International Diversification Puzzle Is Worse Than You Think. American Economic Review, 87(1), 170-180.

Benabou, R. (1996). Heterogeneity, Stratification, and Growth: Macroeconomic Implications of Community Structure and School Finance. American Economic Review, 86(3), 584-609.

Bolan, M. (1997). The Mobility Experience and Neighborhood Attachment. Demography, 34(2), 225-237. https://doi.org/10.2307/2061701

Bonaiuto, M., A. Aiello, M. Perugini, M. Bonnes, \& A. P. Ercolani. (1999). Multidimensional Perception of Residential Environment Quality and Neighbourhood Attachment in the Urban Environment. Journal of Environmental Psychology, 19(4), 331-352. https://doi.org/10.1006/jevp.1999.0138

Bourdieu, P., \& L. Wacquant. (1992). An Invitation to Reflexive Sociology: An Invitation to Reflexive Sociology. Chicago: University Chicago Press.

Bowes, A., N. Dar, \& D. Sim. 91997). Tenure Preference and Housing Strategy: An Exploration of Pakistani Experiences. Housing Studies, 12(1), 63-84. https://doi.org/10.1080/02673039708720883

Brown, B. B., D. D. Perkins, \& G. Brown. (2004). Incivilities, Place Attachment and Crime: Block and Individual Effects. Journal of Environmental Psychology, 24(3), 359-371. https://doi.org/10.1016/j.jenvp.2004.01.001

Brown, B., D. D. Perkins, \& G. Brown. (2003). Place Attachment in a Revitalizing Neighborhood: Individual and Block Levels of Analysis. Journal of Environmental Psychology, 23(3), 259-271. https://doi.org/10.1016/S0272-4944(02)00117-2

Brown, L. A., \& E. G. Moore. 91970). Intra-Urban Migration Process - Perspective. General Systems, 15, 109.

Chin, Y. L. (2010). Preference of Housing Adjustment Intentioin under the Impact of Economic Rationality and Social Networks. Journal of Housing Studies, 19(1), 1-27.

Cigno, A., G. C. Giannelli, \& F. C. Rosati. (1998). Voluntary Transfers among Italian Households: Altruistic and Non-Altruistic Explanations. Structural Change and Economic Dynamics, 9(4), 435-451. https://doi.org/10.1016/S0954-349X(98)00044-7

Cochrane, J. H. (2001). Asset Pricing. Princeton and Oxford: Princeton University Press.

Connerly, C. E. (1986). The Impact of Neighborhood Social-Relations on Prospective Mobility. Social Science Quarterly, 67(1), 186-194.

Constantinides, G. M. (1990). Habit Formation - A Resolution of the Equity Premium Puzzle. Journal of Political Economy, 98(3), 519-543. https://doi.org/10.1086/261693

Cooper, M., D. H. Downs, \& G. A. Patterson. (2000). Asymmetric Information and the Predictability of Real Estate Returns. Journal of Real Estate Finance and Economics, 20(2), 225-244. https://doi.org/10.1023/A:1007833506453

Corcoran, M., R. Gordon, D. Laren, \& G. Solon. (1992). The Association between Men's Economic Status and Theii Family and Community Origins. Journal of Human Resources, 27(4), 575-601. https://doi.org/10.2307/146076

Coval, J. D., \& T. J. Moskowitz. (1999). Home Bias at Home: Local Equity Preference in Domestic Portfolios. Journal of Finance, 54(6), 2045-2073. https://doi.org/10.1111/0022-1082.00181

Crane, J. (1991). The Epidemic Theory of Ghettos and Neighborhood Effects on Dropping out and Teenage Childbearing. American Journal of Sociology, 96, 1226-1256. https://doi.org/10.1086/229654

Cuba, L., \& D. M. Hummon. (1993). Constructing a Sense of Home - Place Affiliation and Migration across the Life-Cycle. Sociological Forum, 8(4), 547-572. https://doi.org/10.1007/BF01115211

Cutts, A. C., \& R. A. Van Order. (2005). On the Economics of Subprime Lending. Journal of Real Estate Finance and Economics, 30(2), 167-196. https://doi.org/10.1007/s11146-004-4878-9

Dawkins, C. J. (2006). Are Social Networks the Ties That Bind Families to Neighborhoods?. Housing Studies, 21(6), 867-881. https://doi.org/10.1080/02673030600917776 
Dewit, D. J., A. V. Wister, \& T. K. Burch. (1988). Physical Distance and Social Contact between Elders and Their Adult Children. Research on Aging, 10(1), 56-80. https://doi.org/10.1177/0164027588101003

Dietz, R. D. (2002). The Estimation of Neighborhood Effects in the Social Sciences: An Interdisciplinary Approach. Social Science Research, 31, 539-537. https://doi.org/10.1016/S0049-089X(02)00005-4

DiPasquale, D., \& E. L. Glaeser. (1999). Incentives and Social Capital: Are Homeowners Better Citizens?. Journal of Urban Economics, 45(2), 354-384. https://doi.org/10.1006/juec.1998.2098

Donaldson, J. B., \& R. Mehra. (1984). Comparative Dynamics of an Equilibrium Intertemporal Asset Pricing Model. Review of Economic Studies, 51(3), 491. https://doi.org/10.2307/2297436

Duffie, D. (2001). Dynamic Asset Pricing Theory (3rd ed.). Princeton and Oxford: Princeton University Press.

Durlanf, S. (1996). A Theory of Persistent Income Inequality. Journal of Economic Growth, 1, 75-93. https://doi.org/10.1007/BF00163343

Durlauf, S. N., \& M. Fafchamps. (2005). Social Capital. In P. Aghion, \& S. Durlauf (Eds.), Handbook of Economic Growth (pp. 1639-1699). Amsterdam: Elsevier. https://doi.org/10.1016/s1574-0684(05)01026-9

Feijten, P., P. Hooimeijer, \& C. H. Mulder. (2008). Residential Experience and Residential Environment Choice over the Life-Course. Urban Studies, 45(1), 141-162. https://doi.org/10.1177/0042098007085105

Firoozi, F., D. R. Hollas, R. C. Rutherford, \& T. A. Thomson. (2006). Property Assessments and Information Asymmetry in Residential Real Estate. Journal of Real Estate Research, 28(3), 275-291.

Friend, I., \& M. E. Blume. (1975). Demand for Risky Assets. American Economic Review, 65(5), 900-922.

Garmaise, M. J., \& T. J. Moskowitz. (2004). Confronting Information Asymmetries: Evidence from Real Estate Markets. Review of Financial Studies, 17(2), 405-437. https://doi.org/10.1093/rfs/hhg037

Glaeser, E. L., D. Laibson, \& B. Sacerdote. (2002). An Economic Approach to Social Capital. Economic Journal, 112(483), 437-458. https://doi.org/10.1111/1468-0297.00078

Glanville, J. L., \& P. Paxton. (2007). How Do We Learn to Trust? A Confirmatory Tetrad Analysis of the Sources of Generalized Trust. Social Psychology Quarterly, 70(3), 230-242. https://doi.org/10.1177/019027250707000303

Green, R. K. (2008). Imperfect Information and the Housing Finance Crisis: A Descriptive Overview. Journal of Housing Economics, 17(4), 262-271. https://doi.org/10.1016/j.jhe.2008.09.003

Haurin, D. R., \& H. A. Morrow-Jones. (2006). The Impact of Real Estate Market Knowledge on Tenure Choice: A Comparison of Black and White Households. Housing Policy Debate, 17(4), 625-653. https://doi.org/10.1080/10511482.2006.9521584

Haurin, D. R., R. D. Dietz, \& B. A. Weinberg. (2002). The Impact of Neighborhood Homeownership Rates: A Review of the Theoretical and Empirical Literature. Journal of Housing Research, 13(2), 119-151. https://doi.org/10.2139/ssrn.303398

Hedman, L. (2013). Moving near Family? The Influence of Extended Family on Neighbourhood Choice in an Intra-Urban Context. Population Space and Place, 19(1), 32-45. https://doi.org/10.1002/psp.1703

Henderson, J. V., \& Y. M. Ioannides. (1987). Owner Occupancy - Investment Vs Consumption Demand. Journal of Urban Economics, 21(2), 228-241. https://doi.org/10.1016/0094-1190(87)90016-7

Henretta, J. C., M. S. Hill, W. Li, B. J. Soldo, \& D. A. Wolf. (1997). Selection of Children to Provide Care: The Effect of Earlier Parental Transfers. Journals of Gerontology Series B-Psychological Sciences and Social Sciences, 52, 110-119. https://doi.org/10.1093/geronb/52B.Special_Issue.110

Hung, M. W., \& L. C. So. (2012). How Much Extra Premium Does a Loss-Averse Owner-Occupied Home Buyer Pay for His House?. Journal of Real Estate Finance and Economics, 45(3), 705-722. https://doi.org/10.1007/s11146-010-9293-9

Jacob, J., \& A. Munasib. (2009). Housing Tenure Choice Implications of Social Networks. St. Louis: Federal Reserve Bank of St Louis.

Kasarda, J. D., \& M. Janowitz. (1974). Community Attachment in Mass Society. American Sociological Review, 39(3), 328-339. https://doi.org/10.2307/2094293

Kehoe, P. J. (1983). Dynamics of the Current Account: Theoretical and Empirical Analysis, Dynamics of the Current Account: Theoretical and Empirical Analysis. Harvard University, Cambridge, MA. 
Knijn, T., \& A. Liefbroer. (2006). More Than Kind: Instrumental Support in Families. In P. Dykstra, M. Kalmijn, K. TCM., A. Komter, A. Liefbroer, \& C. Mulder (Eds.), Family Solidarity in the Netherlands. Amsterdam: Dutch University Press.

Krannich, R. S., \& T. Greider. (1984). Personal Well-Being in Rapid Growth and Stable Communities - Multiple Indicators and Contrasting Results. Rural Sociology, 49(4), 541-552.

Landale, N. S., \& A. M. Guest. (1985). Constraints, Satisfaction and Residential-Mobility - Speares Model Reconsidered. Demography, 22(2), 199-222. https://doi.org/10.2307/2061178

Lawton, L., M. Silverstein, \& V. Bengtson. (1994). Affection, Social Contact, and Geographic Distance between Adult Children and Their Parents. Journal of Marriage and the Family, 56(1), 57-68. https://doi.org/10.2307/352701

Levitt, S. D., \& C. Syverson. (2008). Market Distortions When Agents Are Better Informed: The Value of Information in Real Estate Transactions. Review of Economics and Statistics, 90(4), 599-611. https://doi.org/10.1162/rest.90.4.599

Lewicka, M. (2008). Place Attachment, Place Identity, and Place Memory: Restoring the Forgotten City Past. Journal of Environmental Psychology, 28(3), 209-231. https://doi.org/10.1016/j.jenvp.2008.02.001

Lewicka, M. (2010). What Makes Neighborhood Different from Home and City? Effects of Place Scale on Place Attachment. Journal of Environmental Psychology, 30(1), 35-51. https://doi.org/10.1016/j.jenvp.2009.05.004

Lewicka, M. (2013). Localism and Activity as Two Dimensions of People-Place Bonding: The Role of Cultural Capital. Journal of Environmental Psychology, 36, 43-53. https://doi.org/10.1016/j.jenvp.2013.07.002

Lewis, K. K. (1999). Trying to Explain Home Bias in Equities and Consumption. Journal of Economic Literature, 37(2), 571-608. https://doi.org/10.1257/jel.37.2.571

Lowenstein, A. (2002). Solidarity and Conflicts in Coresidence of Three-Generational Immigrant Families from the Former Soviet Union. Journal of Aging Studies, 16(3), 221-241. https://doi.org/10.1016/S0890-4065(02)00047-6

Lucas, R. E. (1978). Asset Prices in an Exchange Economy. Econometrica, 46(6), 1429-1445. https://doi.org/10.2307/1913837

Manski, C. F. (1993). Identification of Endogenous Social Effects - the Reflection Problem. Review of Economic Studies, 60(3), 531-542. https://doi.org/10.2307/2298123

Manski, C. F. (2000). Economic Analysis of Social Interactions. Journal of Economic Perspectives, 14(3), 115-136.

Manzo, L. C. (2005). For Better or Worse: Exploring Multiple Dimensions of Place Meaning. Journal of Environmental Psychology, 25(1), 67-86. https://doi.org/10.1016/j.jenvp.2005.01.002

McGarry, K., \& R. F. Schoeni. (1995). Transfer Behavior in the Health and Retirement Study - Measurement and the Redistribution of Resources within the Family. Journal of Human Resources, 30, S184-S226. https://doi.org/10.2307/146283

McGarry, K., \& R. F. Schoeni. (1997). Transfer Behavior within the Family: Results from the Asset and Health Dynamics Study. Journals of Gerontology Series B-Psychological Sciences and Social Sciences, 52, 82-92.

Mehra, R. (2003). The Equity Premium: Why Is It a Puzzle?. Financial Analysts Journal, 59(1), 54-+. https://doi.org/10.2469/faj.v59.n1.2503

Mehra, R., \& E. C. Prescott. (1985). The Equity Premium - A Puzzle. Journal of Monetary Economics, 15(2), 145-161. https://doi.org/10.1016/0304-3932(85)90061-3

Mehra, R., \& R. Sah. (2002). Mood Fluctuations, Projection Bias, and Volatility of Equity Prices. Journal of Economic Dynamics \& Control, 26(5), 869-887. https://doi.org/10.1016/S0165-1889(01)00035-5

Mesch, G. S., \& G. Manor. (1998). Social Ties, Environmental Perception, and Local Attachment. Environment and Behavior, 30(4), 504-519. https://doi.org/10.1177/001391659803000405

Michielin, F., C. H. Mulder, \& A. Zorlu. (2008). Distance to Parents and Geographical Mobility. Population Space and Place, 14(4), 327-345. https://doi.org/10.1002/psp.509

Mulder, C. H. (2007). The Family Context and Residential Choice: A Challenge for New Research. Population Space and Place, 13(4), 265-278. https://doi.org/10.1002/psp.456 
Munasib, A. (2009). Housing Tenure Choice Implications of Social Networks: A Structural Model Approach. St. Louis: Federal Reserve Bank of St Louis.

Nanda, A., \& S. L. Ross. (2012). The Impact of Property Condition Disclosure Laws on Housing Prices: Evidence from an Event Study Using Propensity Scores. Journal of Real Estate Finance and Economics, 45(1), 88-109. https://doi.org/10.1007/s11146-009-9206-y

Nelson, J. P. (1978). Residential Choice, Hedonic Prices, and Demand for Urban Air-Quality. Journal of Urban Economics, 5(3), 357-369. https://doi.org/10.1016/0094-1190(78)90016-5

Nelson, J. P. (1979). Airport Noise, Location Rent, and the Market for Residential Amenities. Journal of Environmental Economics and Management, 6(4), 320-331. https://doi.org/10.1016/0095-0696(79)90011-1

Nelson, J. P. (1980). Airports and Property-Values - Survey of Recent-Evidence. Journal of Transport Economics and Policy, 14(1), 37-52.

Nelson, J. P. (1982). Highway Noise and Property-Values - a Survey of Recent-Evidence. Journal of Transport Economics and Policy, 16(2), 117-138.

Ng, A. C. Y., D. R. Phillips, \& W. K. M. Lee. (2002). Persistence and Challenges to Filial Piety and Informal Support of Older Persons in a Modern Chinese Society: A Case Study in Tuen Mun, Hong Kong. Journal of Aging Studies, 16(2), 135-153. https://doi.org/10.1016/S0890-4065(02)00040-3

Ng, S. H., P. K. Kam, \& R. W. M. Pong. (2005). People Living in Ageing Buildings: Their Quality of Life and Sense of Belonging. Journal of Environmental Psychology, 25(3), 347-360. https://doi.org/10.1016/j.jenvp.2005.08.005

Oishi, S., A. J. Rothman, M. Snyder, J. Su, K. Zehm, A. W. Hertel, et al. (2007). The Socioecological Model of Procommunity Action: The Benefits of Residential Stability. Journal of Personality and Social Psychology, 93(5), 831-844. https://doi.org/10.1037/0022-3514.93.5.831

Pezzin, L. E., \& B. S. Schone. (1999). Intergenerational Household Formation, Female Labor Supply and Informal Caregiving - a Bargaining Approach. Journal of Human Resources, 34(3), 475-503. https://doi.org/10.2307/146377

Pope, J. C. (2008). Buyer Information and the Hedonic: The Impact of a Seller Disclosure on the Implicit Price for Airport Noise. Journal of Urban Economics, 63(2), 498-516. https://doi.org/10.1016/j.jue.2007.03.003

Portes, A., \& P. Landolt. (1996). The Downside of Social Capital, The American Prospect, 94, 18-21.

Prescott, E. C., \& R. Mehra. (1980). Recursive Competitive Equilibrium: The Case of Homogeneous Households. Econometrica, 48(6), 1365-1379. https://doi.org/10.2307/1912812

Quigley, J., \& D. Weinber. (1977). Intra-Urban Residential Mobility: A Review and Synthesis. International Regional Science Review, 2, 41-66. https://doi.org/10.1177/016001767700200104

Ringel, N. B., \& J. C. Finkelstein. (1991). Differentiating Neighborhood Satisfaction and Neighborhood Attachment among Urban Residents. Basic and Applied Social Psychology, 12(2), 177-193. https://doi.org/10.1207/s15324834basp1202_4

Rutherford, R. C., T. M. Springer, \& A. Yavas. (2007). Evidence of Information Asymmetries in the Market for Residential Condominiums. Journal of Real Estate Finance and Economics, 35(1), 23-38. https://doi.org/10.1007/s11146-007-9027-9

Shamai, S., \& Z. Ilatov. (2005). Measuring Sense of Place: Methodological Aspects. Tijdschrift Voor Economische En Sociale Geografie, 96(5), 467-476. https://doi.org/10.1111/j.1467-9663.2005.00479.x

Shu, H. C. (2010). Investor Mood and Financial Markets. Journal of Economic Behavior \& Organization, 76(2), 267-282. https://doi.org/10.1016/j.jebo.2010.06.004

Simon, H. A. (1957). Models of Man. New York: John Wiley.

Soldo, B. J., \& M. S. Hill. (1995). Family Structure and Transfer Measures in the Health and Retirement Study Background and Overview. Journal of Human Resources, 30, S108-S137. https://doi.org/10.2307/146280

Spilimbergo, A., \& L. Ubeda. (2004). Family Attachment and the Decision to Move by Race. Journal of Urban Economics, 55(3), 478-497. https://doi.org/10.1016/j.jue.2003.07.004 
Tobin, J., \& W. Dolde. (1971). Wealth, Liquidity and Consumption. In Consumer Spending and Monetary Policy (pp. 99-146). Federal Reserve Bank of Boston, Boston, MA.

Tomassini, C., D. A. Wolf, \& A. Rosina. (2003). Parental Housing Assistance and Parent-Child Proximity in Italy. Journal of Marriage and Family, 65(3), 700-715. https://doi.org/10.1111/j.1741-3737.2003.00700.x

van Kempen, R., \& A. S. Ozuekren. (1998). Ethnic Segregation in Cities: New Forms and Explanations in a Dynamic World. Urban Studies, 35(10), 1631-1656. https://doi.org/10.1080/0042098984088

Wall, T., \& C. Von Reichert. (2013). Divorce as an Influence in Return Migration to Rural Areas. Population Space and Place, 19(3), 350-363. https://doi.org/10.1002/psp.1719

Wojcik, A., M. Bilewicz, \& M. Lewicka. (2010). Living on the Ashes: Collective Representations of Polish-Jewish History among People Living in the Former Warsaw Ghetto Area. Cities, 27(4), 195-203. https://doi.org/10.1016/j.cities.2010.01.002

Wong, S. K., C. Y. Yiu, \& K. W. Chau. (2012). Liquidity and Information Asymmetry in the Real Estate Market. Journal of Real Estate Finance and Economics, 45(1), 49-62. https://doi.org/10.1007/s11146-011-9326-z

Zorlu, A. (2009). Ethnic Differences in Spatial Mobility: The Impact of Family Ties. Population Space and Place, 15(4), 323-342. https://doi.org/10.1002/psp.560

\section{Notes}

Note 1. The definition of emotional attachment is consistent with most literatures. Lewicka (2010) pointed out that all the literature which is related to place attachment, about $70 \%$ investigate attachment to neighborhood or community, about $20 \%$ study attachment to dwelling.

Note 2. The similar settings of the consumption growth rate is applied in stock market prices, such as Meha and Prescott (1985), Mehra and Sah (2002), Mehra (2003) and Shu (2010).

\section{Appendix A}

Induction process of Eqns. (9) and (10)

Because $\ln g_{t+1} \sim N\left(\mu-\frac{\sigma^{2}}{2}, \sigma^{2}\right)$, we can get

$$
\begin{gathered}
-\phi \ln g_{t+1} \sim N\left(-\phi\left(\mu-\frac{\sigma^{2}}{2}\right), \phi^{2} \sigma^{2}\right), \\
(1-\phi) \ln g_{t+1} \sim N\left((1-\phi)\left(\mu-\frac{\sigma^{2}}{2}\right),(1-\phi)^{2} \sigma^{2}\right),
\end{gathered}
$$

Thus,

$$
\begin{gathered}
E\left[g_{t+1}^{-\phi}\right]=E\left[\exp \left(-\phi \ln g_{t+1}\right)\right]=\exp \left[\phi\left(\frac{\phi \sigma^{2}}{2}+\frac{\sigma^{2}}{2}-\mu\right)\right] \\
E\left[g_{t+1}^{(1-\phi)}\right]=E\left[\exp \left((1-\phi) \ln g_{t+1}\right)\right]=\exp \left[(1-\phi)\left(\mu-\frac{\phi \sigma^{2}}{2}\right)\right]
\end{gathered}
$$

Equations (A.3) and (A.4) are identical to Eqns. (9) and (10) in this study. 


\section{Appendix B}

For robustness checks, I redraw Eqns. (13) - (16) for $\phi=1,2$, and 3. All results are respectively displayed in Figures 5-8, which are consistent with Figures 1-4.

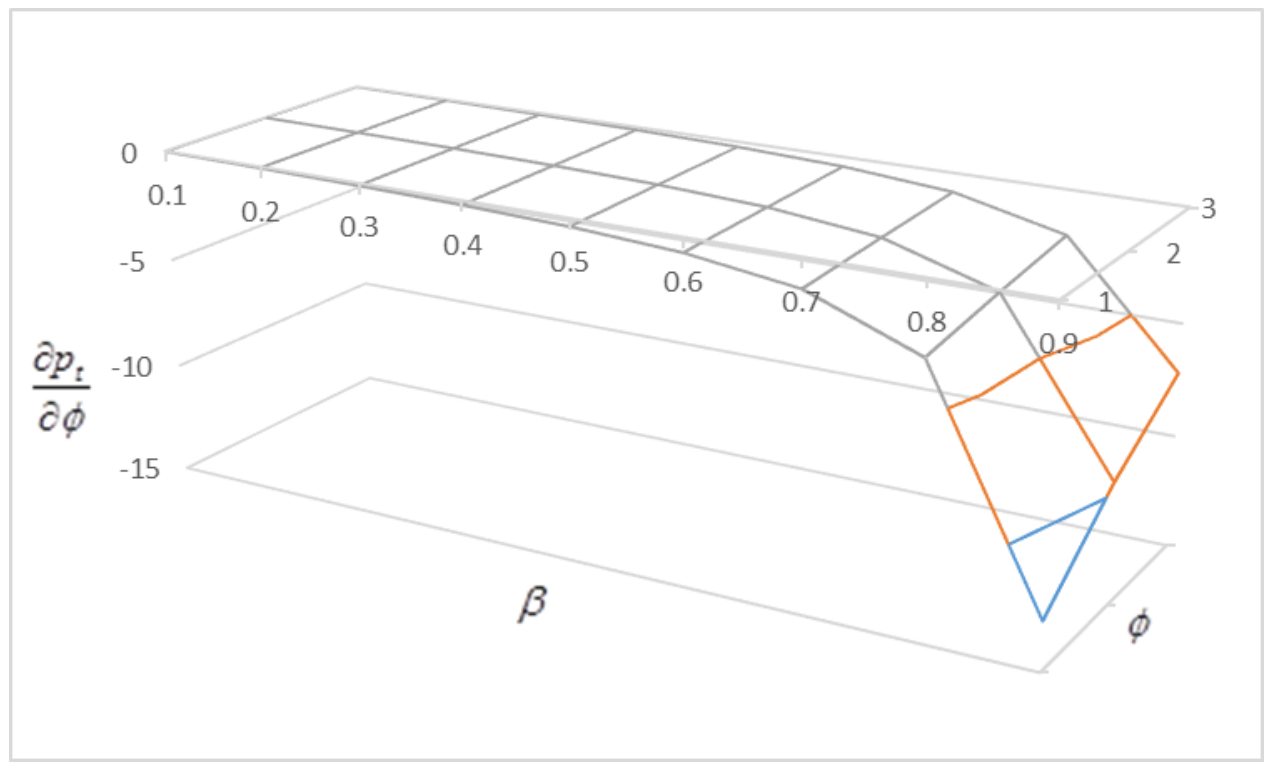

Figure 5. The partial derivative of property price to home bias factor (for $\phi=1,2$, and 3)

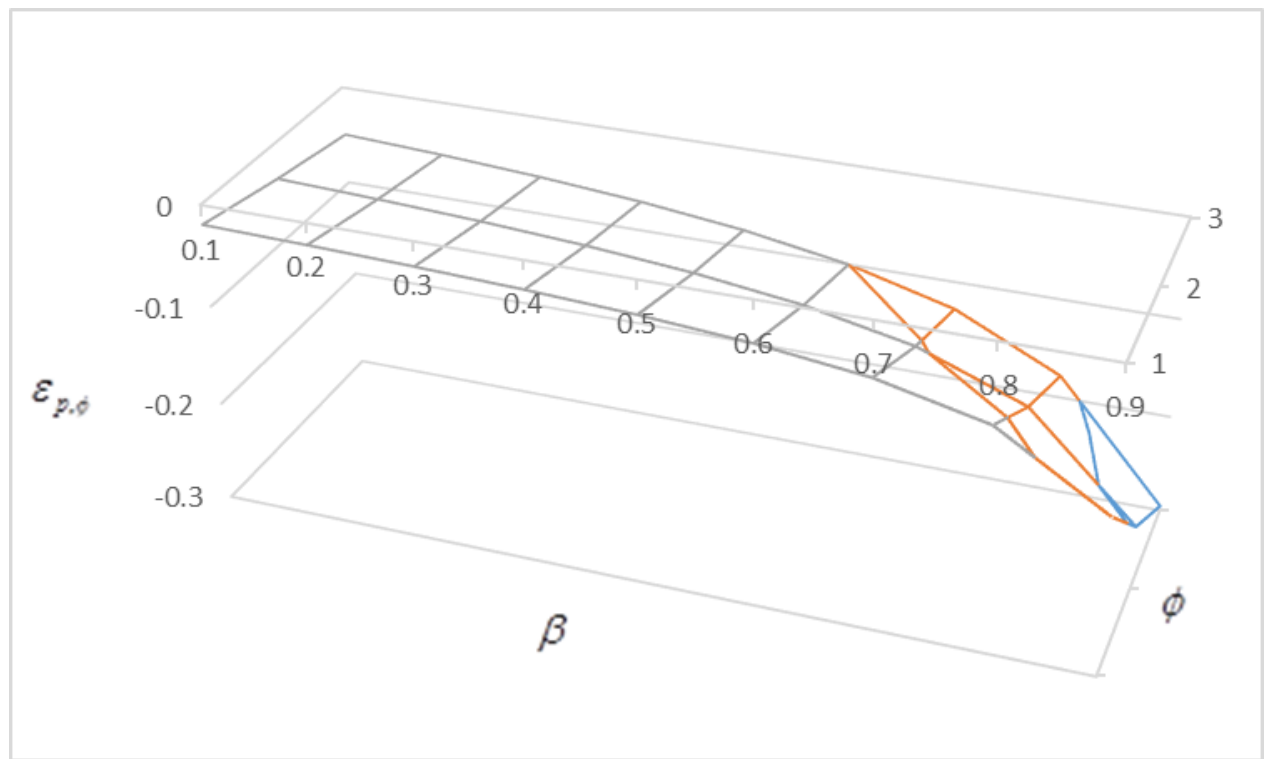

Figure 6. The coefficient of the home bias elasticity of price (for $\phi=1,2$, and 3) 


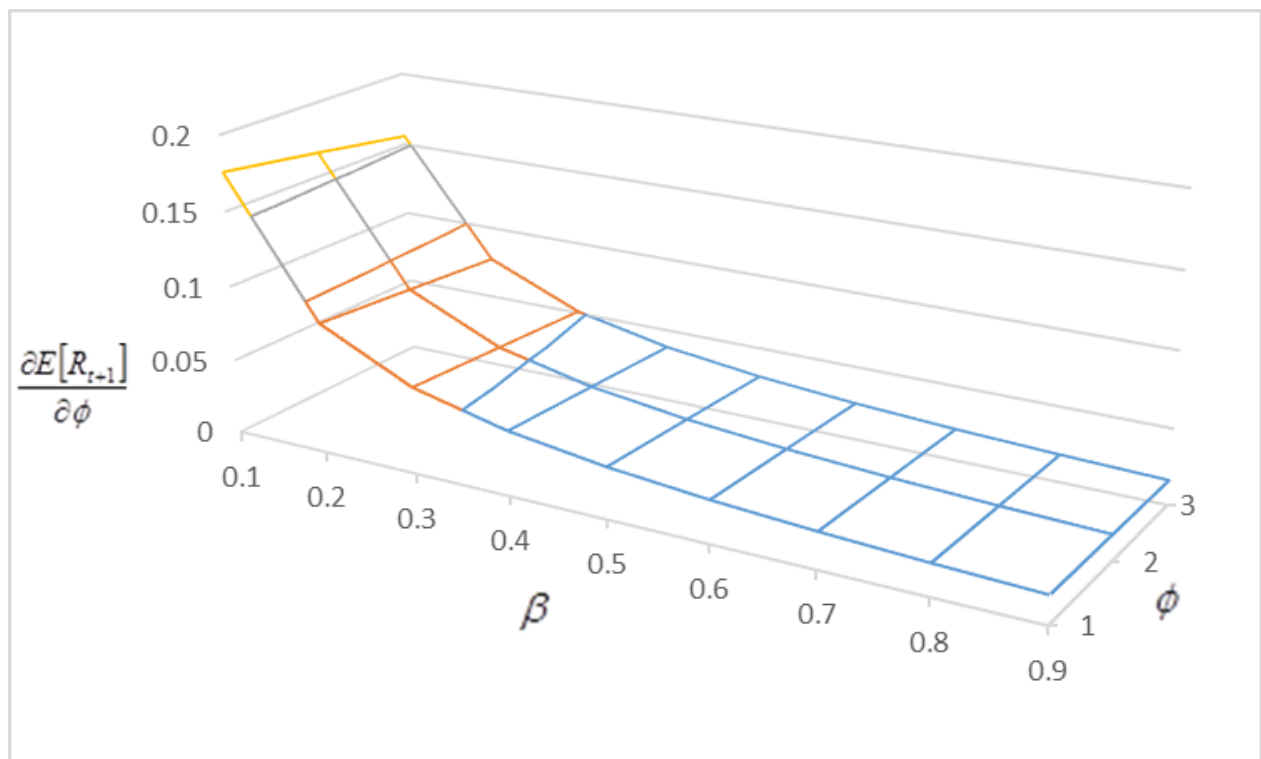

Figure 7. The partial derivative of returns to home bias factor (for $\phi=1,2$, and 3)

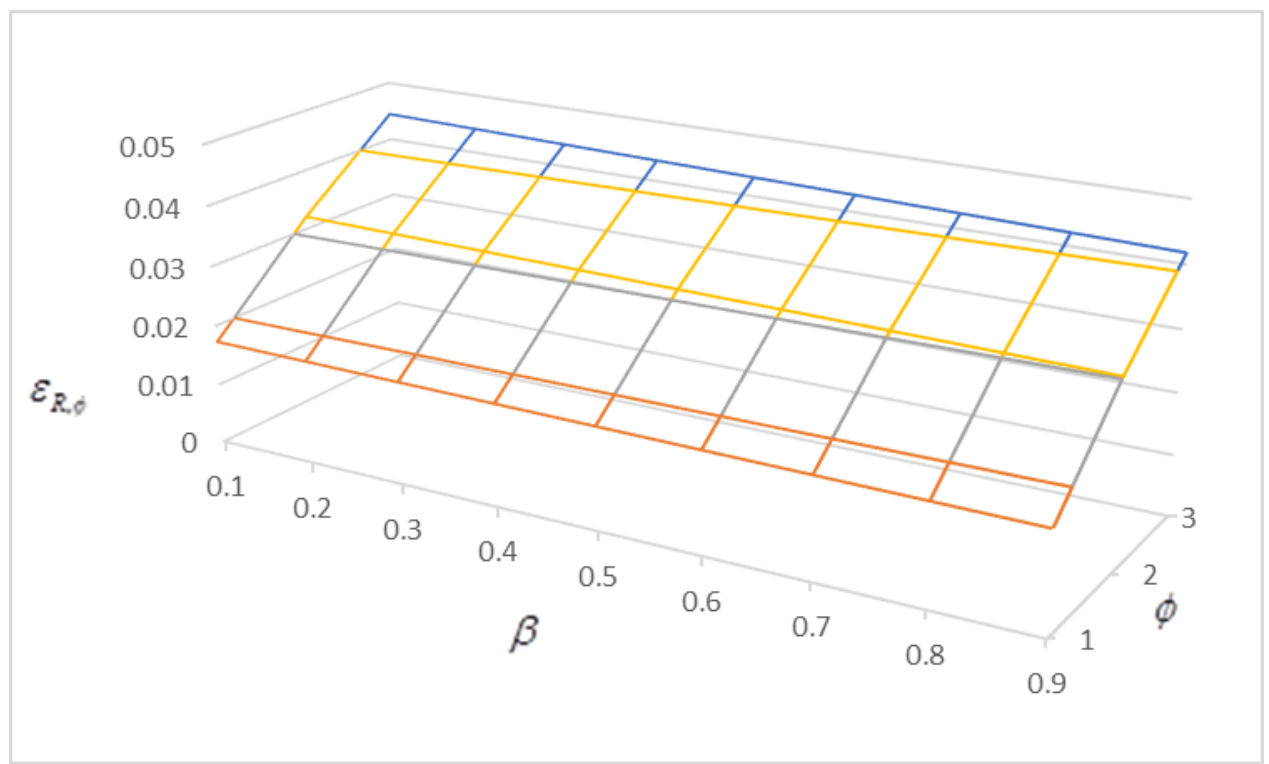

Figure 8. The coefficient of the home bias elasticity of return (for $\phi=1,2$, and 3 ) 